\title{
Spatial Variation in Households' Defensible Response in Oke-Ogun Area of Oyo State, Nigeria
}

\author{
IGE James Olateju $^{1} \quad$ ADIGUN Folasade $\mathrm{O}^{1^{*}} \quad$ ABOLADE Olajoke $^{1} \quad$ AGUDA Samuel A. $^{2}$ \\ 1.Department of Urban and Regional Planning, Ladoke Akintola University of Technology, Faculty of \\ Environmental Sciences, Ogbomoso, Oyo State, Nigeria. \\ 2.Department of Geography Obafemi Awolowo University, Ile-Ife \\ *Corresponding Author
}

\begin{abstract}
The paper assessed households' use and location of security barriers and surveillance structure in Oke-Ogun area of Oyo State with a view to examining spatial variation in households' response to crime in the area. Both primary and secondary data were employed. The total households of urban and rural settlements as identified in Oke-Ogun area of Oyo State were 44,421 and 175,568 respectively The sample frame constituted all households in the study area, and five out of 1000 of all the 219,989 total households which approximately amount to 1100 households constituted the sample size, Random sampling was employed in hierarchical selection of $5 \%$ of the total households in each settlement type, and a total number of 1100 copies of questionnaires were randomly administered Descriptive statistics such as percentage and Chi-Square were used to present summary of findings.. Findings revealed that fence, security gates/checkpoints and burglary guards were among the security barriers used. Higher order security consciousness was displayed in urban area with a substantial proportion of buildings surveyed $(57.8 \%)$ having burglar guard on windows compared with $54.5 \%$ in the rural settlements. Observation from actual existence revealed that the quality of burglar guards in terms of strength and durability conformed to a regular spatial pattern; and that quality improved with increasing sizes (from rural to urban settlement) of settlement types. Also, surveillance structure in Oke-Ogun included the use of private security personnel which was at its lowest intensity and only $13.4 \%$ of all households surveyed signifying its usage. Vigilante group dominates every other security measures across the settlement types. The study concluded that response to crime in the area varied spatially.
\end{abstract}

Keywords: Crime, Household, Surveillance, Security barriers

DOI: $10.7176 / \mathrm{JLPG} / 89-18$

Publication date:September $30^{\text {th }} 2019$

\section{Introduction}

Crime is a global cankerworm and one of the most notable threats to rural liveability and urban development. In Nigeria, crime has all day long become a hydra-headed social monster pervading every dimension of human survival and stable life style. One is reminded of insecurity everywhere one goes in Nigeria. It is not just the window guards, burglar-proofs, fortified gates, security ramparts, sky rocketing defensive walls and the day by day news of bolder and more sophisticated crimes that indicate rampant menace, but the increased growth of troop movements in the neighbourhoods and the presence, day and night, of law enforcement agents and other armed guards patrolling the streets, highways and borders.

Crime, as Omisakin (1998) expressed, "is a social menace, an undeniable stigma to national image and a significant source of threat to people's safety and wellbeing”. Increasingly, people daily depend on the protection of vigilante groups and engage in fencing the home, learning and business environments; erecting neighbourhood gates and checkpoints. Private security agents are intensively hired by organisations and individuals who can afford to pay for a multitude of motives. These motives include deep-seated fears that crime will infringe on safe neighbourhoods, which are largely due to the perceived increasing intricacy of the society, and the reality of the finiteness and limitations of government resources that could be put at the disposal of effective neighbourhood policing.

Day in, day out, safe and peaceful existence is worrisomely becoming a fiction of the past in many Nigerian neighbourhoods. Lives are constantly being threatened at residences, on the streets, even at places of worship (Adigun, 2012). At this juncture, there must be reconciliation with the fact that crime does not occur in vacuum and all its concomitant adhesions with society that are likened to two inseparable opposite sides of a coin are a problem worth studying. A "crime" as Peet (1975) rightly observes, "is a surface expression of discontents which lie deeply embedded in social system". Planning and development take place in geographic space. Routine Activity Theory and Defensible Space Concept predict that the circumstances that foster or deter crime are functions of social and structural factors that enable people to translate their criminal motivation into action (Felson, 1998). Environmental design, therefore, impacts on social problem, but it is difficult to generalize spatial dichotomy in crime occurrence and prevention between urban and rural environments. The degree of responsiveness of planning programmes often depends on how adequately or otherwise the relevant problem area has been identified. Friedmann (1960) has argued that nothing of a substance can be achieved by the planner 
until the right set of problem regions is identified and the right set of studies is carried out. Ige et al, (2010) has also asserted that any meaningful and sustainable policies and programmes targeted at curtailing criminal activities and improving the quality of human life while living within the carrying capacity of supporting ecosystem in the communities must take into consideration the physical environment within which crime occurs in various locations. Therefore, responses to crime has not been comprehensively studied in Nigeria because urban crime pattern pervades her limited crime research efforts. There is enough information to conclude that the magnitude of the problem is quite serious and that Nigeria's crime problem is essentially beyond urban environment. The severity of crime in Nigeria is evident in daily news of bolder and more sophisticated crimes in both rural and urban places, despite the age long crime research and long history of present crime control measures, that urban environment with an overall conception of and policy on crime and its control have no less serious crime effects than rural environment. In the light of the foregoing, it is imperative that we understand how crime incidence is controlled with a view to providing better information that will facilitate effective policy response for ameliorating crime occurrence and its associated effects.

The study therefore aims at analysing households' responses to crime in Oke-Ogun area of Oyo State. The objectives of the study are to examine households' use and location of security barriers, assess surveillance structure and households' preference for keeping Neighbourhood safe in Oke-Ogun.

\section{Materials and Method}

The Study Area

The study area is Oke-Ogun area in Oyo State. Oke-Ogun area is the north-western region of Oyo State, and is made up of rural communities and large rural centres (small towns) located in the northern and north-western parts of Oyo State, Nigeria. Geographically, Oke-Ogun approximately stretches between latitudes $07^{\circ} 28^{\prime}$ and $08^{\circ} 38^{\prime}$ North and longitudes $03^{\circ} 02^{\prime}$ and $04^{\circ} 44^{\prime}$ East (Figure 1). Oke-Ogun shares boundary with Kwara State in the North, in the South by Ogun State, Ibarapa North and Ibarapa East local government areas; in the East by Atiba and Oyo West local government areas, and in the West by Republic of Benin

Oke-Ogun area is a borderland consisting of ten local government areas. The ten LGAs are districted into three zones, namely;

(i) Border zone: This comprises Saki West, Atisbo and Iwajowa local government areas. The local government areas within this zone share boundary with the Republic of Benin

(ii) Near border zone: This comprises Saki East, Itesiwaju, Kajola and Iseyin local government areas. These local government areas share boundary with the local government areas sharing boundary with the Republic of Benin. This implies that they are indirectly connected to the border.

(iii) Far border zone: It comprises Orelope, Olorunsogo and Irepo local government areas. These local government areas share boundary with Kwara State which shares boundary with the Republic of Benin. Also, these local government areas are indirectly connected to the border. The people of Oke-Ogun are mostly Yoruba. The regional accent of Oke-Ogun is called "Onko". Some ethnic groups like Ibaruba, Filani, Aketepe, and foreigners from Republic of Benin and Togo are found practising agriculture in the area.

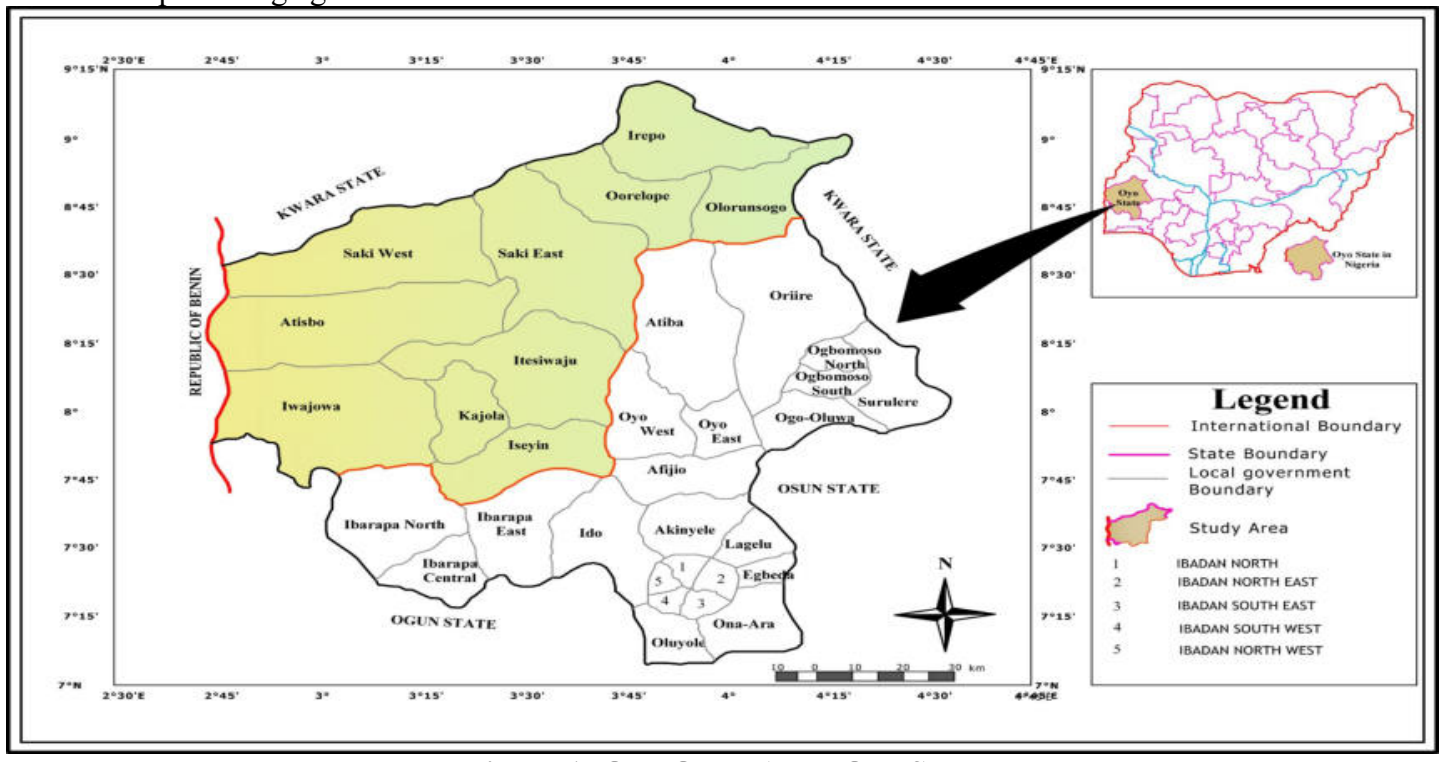

Figure 1: Oke-Ogun Area, Oyo State 


\section{Data Collection and Analysis}

Data for this study were obtained from both primary and secondary sources. The data from primary sources were obtained through questionnaire, direct observation and oral interview. Questionnaire was used to obtain information on form of preventive measures put in place in the residence as means of making their respective neighbourhoods safer. In-depth interview was conducted on selected landlord and tenant, opinion leaders and security agents who lived in the settlement for not less than two years to complement the direct observation and questionnaire administration. Secondary data for this study included published materials, population reports and data from National Population Commission. In addition, digitized map of Oke-Ogun was obtained from the GIS laboratory of the Department of Urban and Regional Planning, Ladoke Akintola University of Technology, Ogbomoso.

All households in Oke-Ogun constituted the sample frame. Total Population and households of Oke-Ogun as extracted from 1991 National Population Census were 663,363 and 118,784 respectively. The projected population from 1991 to 2013 using growth rate of 2.8\% and total households of Oke-Ogun as obtained from National Population Commission (NPC) were 1,228,548 and 219,987 respectively The total households of urban and rural settlements as identified in Oke-Ogun area of Oyo State were 44,421 and 175,566 respectively. Based on this population and household size, a certain proportion was used for the sample survey. To arrive at the sample size, sampling ratio of $0.5 \%$ of the total households was used and this constituted $0.9 \%$ of the total population in Oke-Ogun. The decision for the choices of $0.5 \%$ of all household was premised on assertion of Neuman (1994) that larger population permits smaller sampling ratio for equally good samples. Neumann's argument is that, as population size grows, the returns in accuracy for sample size shrinks. Also, Adigun (2012) reported that Singleton et al, (1989) suggested 0.05 percent as a good proportion for sample survey of large population.

The sample frame constituted all households in the study area, and five out of 1000 of all the 219,989 total households which approximately amount to 1100 households constituted the sample size, In all, $5 \%$ of the total households were sampled and a total number of 1100 copies of questionnaires were administered to matured residents from 1100 randomly selected households

A multi-stage sampling procedure was used to collect primary data through questionnaire administration. In the first stage, settlements in the study area were stratified into two settlement types; rural and urban settlements in each of the 10 Local Government Areas (LGAs) in Oke-Ogun area of Oyo State, based on population of 20,000 persons and above for urban and less than 20,000 persons for rural settlements.

In the second stage, five per thousand $(5 \%)$ of total households in every local government area was considered. Then, a total of 5 settlements were purposively selected in each of the 10 local government areas, using a ratio of 1(urban): 4 (rural), based on settlement hierarchical selection model, (i.e., the ratio is based on the premise of average population distribution pattern among settlements). Then, one urban and four rural settlements were randomly chosen. Copies of the questionnaire were, therefore, administered to five out of every 1000 of total households in urban and rural settlements of all the 10 LGAs in Oke-Ogun area.

In the third stage, five out of 1000 of all the 219,989 total households which approximately amount to 1100 households constitute the sample size. The total number of questionnaires administered in all 10 local government areas selected was therefore 1100. The numbers given to housing units for enumeration area demarcation for 2006 population census by National Population Commission, and a good proportion of newly constructed buildings that were outnumbered were updated, and both compiled for the selected settlement types (urban and rural) in each local government area of Oke-Ogun. From the compiled lists, required housing units were randomly selected in each of the selected settlement types. One of all persons aged 18 years and above was purposively interviewed in each selected household. Notwithstanding, children were also given the privilege of responding to the oral questions. There was, however, exceptional cases like multi-household buildings (more than one household occupying only one building): The household with longest stay in the housing unit was selected. In a multi-building single household (a single household occupying more than one building). This is a common feature of the traditional Yoruba settlements as a result of the polygamous and extended nature of Yoruba families. If two or more housing units randomly selected were of multi-building single household, only one housing unit was used while others were skipped. In this case, only one questionnaire was used just like any other household, while the remaining questionnaires were used for the nearest unselected housing unit(s) from a compiled list of housing units for the particular settlement under investigation. It is equally noteworthy to mention that there were some cases where housing units selected were empty (either unoccupied or households not at home) such housings units were skipped to the nearest unselected housing units.

Method of data analysis for data collected were mainly descriptive. Descriptive statistics were appropriately used in the analysis of results to present certain discussions and to depict vividly a summary description of the various responses for a sample drawn from a population of households. Chi-Square was used to determine level of significant difference between some elements of defence in the households and community. 


\section{Results and Discussion}

The protective measures are explained within the concepts of Defensible Space Concepts and application of the elements of Crime Prevention through Environmental Design (CPTED). The elements considered to create secure environment by residents include security barrier, territoriality, surveillance, lighting and landscaping.

\section{(i) Use and Location of Security Barriers in Oke-Ogun}

Fence, fencing material, height of the fence and material on the top of fence, burglar guard, burglar guard material, location of burglar guard on structures, material used window and doors were among the security barrier studied.

\section{Burglar Proof}

The analysis of data collected on the use of burglar guard as security barrier across settlement types in Oke-Ogun revealed that $13.9 \%$ of all the buildings sampled had no burglar guard, while a good proportion $(86.1 \%)$ had it at various degrees (Table 1). Out of $86.1 \%$ aforementioned, $55.2 \%$ had it installed on window only, $19.4 \%$ on windows and doors, and $4.2 \%$ on door only while $7.4 \%$ on all openings into the buildings. The higher proportion of all the buildings without burglar proof (14.5\%) were found in the rural settlements while $11.5 \%$ of buildings without burglar proof were found in urban settlements. Higher order security consciousness was displayed in urban, in line with expectation, with a substantial proportion of buildings (57.8\%) having burglar guard on windows compared with $54.5 \%$ in the rural settlements (Table 1). The chi-square performed across settlement types at $(\mathrm{P}<0.05)$ indicates that the difference in location of installed burglary was significant. The implication of this is that there was a significant difference between location of installed burglary by households and the settlement types in Oke-Ogun.

Table 1 Location of Installed Burglary

\begin{tabular}{|l|l|l|l|l|l|l|}
\hline \multirow{2}{*}{ Location of Burglary } & \multicolumn{7}{|c|}{ Settlement } \\
\cline { 2 - 7 } & Rural & Urban & Total \\
\cline { 2 - 7 } & Freq & $\%$ & Freq & $\%$ & Freq & $\%$ \\
\hline Absent & 125 & 14.5 & 25 & 11.5 & 150 & 13.9 \\
\hline On window only & 471 & 54.5 & 125 & 57.8 & 597 & 55.2 \\
\hline On window \& doors & 154 & 17.8 & 56 & 25.7 & 210 & 19.4 \\
\hline On door only & 41 & 4.7 & 4 & 1.8 & 43 & 4.2 \\
\hline On all opening & 73 & 8.4 & 7 & 3.2 & 80 & 7.4 \\
\hline Total & 864 & 100.0 & 218 & 100.0 & 1062 & 100.0 \\
\hline
\end{tabular}

Source: Field Research, $2014 \quad \mathrm{X}^{2}=17.02$, Df $=4(\mathrm{P}>0.05)=7.78$

The installation of burglar guard in the urban settlements was not only high to showcase their high level security consciousness but also of high quality in material used. In line with expectation, the greatest proportion of buildings with iron/steel works (85.3\%) were found in urban, and $70.1 \%$ of iron/steel works in rural settlements (Table 2).

Rural settlements took the lead while urban settlements followed in the use of planks and others like (woven grass) as material for burglary guard. Also, the use of concrete mullion also dominated the rural settlements with $5.7 \%$ compared with $1.4 \%$ urban settlements. Wood/plank, woven grass, wire mesh and concrete mullion are considered weaker burglar guard than iron-steel. The strength of window and door guard used by the households might partly depend on the degree of security consciousness of the households. This consciousness might be majorly based on actual experience of crime or the fear of crime. The Pearson chi-square performed at 0.05 level of significance indicated that there was significant difference in the use of burglar guard among settlement types (Table 2). As observed from actual existence, the quality of burglar guards in terms of strength and durability conformed to a regular spatial pattern; and that quality improved with increasing sizes (from rural to urban settlement) of settlement types.

Table 2 Material Used for Burglary Guard

\begin{tabular}{|l|l|l|l|l|l|l|}
\hline \multirow{2}{*}{ Material Used } & \multicolumn{9}{|c|}{ Settlement } \\
\cline { 2 - 7 } & Rural & Urban & Total \\
\cline { 2 - 7 } & Freq & $\%$ & Freq & $\%$ & Freq & $\%$ \\
\hline Planks & 119 & 15.1 & 6 & 2.8 & 125 & 12.5 \\
\hline Wire mesh & 49 & 6.2 & 14 & 6.6 & 53 & 6.3 \\
\hline Iron/steel & 520 & 66.0 & 180 & 85.3 & 700 & 70.1 \\
\hline Concrete mullion & 45 & 5.7 & 3 & 1.4 & 48 & 4.8 \\
\hline Others & 55 & 7.0 & 8 & 3.8 & 63 & 6.3 \\
\hline Total & 788 & 100.0 & 211 & 100.0 & 999 & 100.0 \\
\hline
\end{tabular}

Source: Field Research, $2014 \quad \mathrm{X}^{2}=37.99 \mathrm{Df}=4(\mathrm{P}<0.05)=7.78$ 
Door and Window Materials

The commonly used material for door making was iron/steel (44.6\%) followed by wood/plank (43.0\%) and flush door $(10,6 \%)$ then glass panes $(1.8 \%)$. A very good proportion $(54.3 \%)$ of iron/steel doors were found in urban settlements compared with below average proportion of $44.6 \%$ in the rural settlements. The use of wood/plank dominated the door materials in rural areas while the use of iron/steel dominated in urban settlements (Table 3).

Table 3 Materials Used for Door

\begin{tabular}{|l|l|l|l|l|l|l|}
\hline \multirow{2}{*}{ Material } & \multicolumn{7}{|c|}{ Settlement } \\
\cline { 2 - 7 } & Rural & Urban & \multicolumn{2}{l|}{ Total } \\
\cline { 2 - 7 } & Freq & $\%$ & Freq & $\%$ & Freq & $\%$ \\
\hline Wood/plank & 367 & 45.2 & 72 & 34.6 & 439 & 43.0 \\
\hline Iron/steel & 342 & 42.1 & 113 & 54.3 & 455 & 44.6 \\
\hline Flush door & 93 & 11.5 & 15 & 7.2 & 106 & 10.6 \\
\hline Glass panes & 10 & 1.2 & 8 & 3.6 & 18 & 1.8 \\
\hline Total & 12 & 100.0 & 208 & 100.0 & 1020 & 1020 \\
\hline
\end{tabular}

Source: Field Research, $2014 \quad \mathrm{X}^{2}=19.05 \mathrm{Df}=3(\mathrm{P}<0.05)=6.25$

\section{Materials Used for Window}

The analysis of data collected on materials used for window in Oke-Ogun Region revealed that glass pane $(42.7 \%)$ was the commonly used materials, followed by wood plank $(34.0 \%)$ and iron/steel $(21.2 \%)$, then louver blade $2.0 \%$ ). Urban settlements do not conform to the distribution pattern on the use of material for window as obtained at spatially aggregated level. The use of iron/steel was ranked second instead of wood/ plank (Table 4). From direct observation and in-depth interview the quality of materials used for window tends to be a function of affluence. Also, the chi-square performed across settlement types at $(\mathrm{P}<0.05)$ indicates that the difference in materials used for window is significant. The implication of this is that there is a significant difference between materials used for window by households and the settlement types in Oke-Ogun.

Table 4 Materials used for Window

\begin{tabular}{|l|l|l|l|l|l|l|}
\hline \multirow{3}{*}{ Material used } & \multicolumn{7}{|c|}{ Settlement } \\
\cline { 2 - 7 } & Rural & Urban & Total \\
\cline { 2 - 7 } & Freq & $\%$ & Freq & $\%$ & Freq & $\%$ \\
\hline Wood plank & 317 & 38.8 & 34 & 16.0 & 351 & 34.0 \\
\hline Iron/steel & 171 & 20.9 & 48 & 22.5 & 219 & 21.2 \\
\hline Glass panes & 326 & 39.9 & 114 & 53.5 & 440 & 42.7 \\
\hline Louver blade & 4 & 5 & 17 & 8.0 & 21 & 2.0 \\
\hline Total & 818 & 100 & 213 & 100.0 & 1031 & 100.00 \\
\hline
\end{tabular}

Source: Field Research, $2014 \quad \mathrm{X}^{2}=79.99 \mathrm{Df}=2(\mathrm{P}<0.05)=4.80$

The materials used for door and window guard more often than not might not only depict affluence but also indicate the level of security consciousness of the inhabitants. Wood plank is considered to be of lower quality and a less effective security barrier when compared with iron/steel works. Iron / steel are considered a stronger material for window and doors. The uses of windows and doors that are made up of wood plank and iron/steel are defeated based on translucency to see through except in few cases where glass panes are inserted into a leaf of a wooden and steel door and or fanlight of wooden windows to provide the transparency needed. However, flush doors, glass panes and louver blades are fashionable and high level security barriers, though they are not as strong as wooden and iron/steel materials yet transparent enough to detect intrusive interference of intruders from inside the buildings without intruders' knowledge. Every coin has two sides, the use of iron/steel works as a burglar guard material prevent easy entry into property by increasing time of criminal operation, this speed up the risk of criminal being caught and therefore act as a more effective security barrier.

Fencing and Material Used

More than one-third (37.1\%) of the building sampled had no fence in the Oke-Ogun. In line with expectation, $38.8 \%$ of the building sampled in the rural settlement had no fence while $30.6 \%$ of the building sampled in the urban settlements had no fence (Table 5) 
Table 5 Materials Used for Fence

\begin{tabular}{|c|c|c|c|c|c|c|}
\hline \multirow{3}{*}{ Material } & \multicolumn{6}{|c|}{ Settlement } \\
\hline & \multicolumn{2}{|c|}{ Rural } & \multicolumn{2}{|c|}{ Urban } & \multicolumn{2}{|l|}{ Total } \\
\hline & Freq & $\%$ & Freq & $\%$ & Freq & $\%$ \\
\hline Hedges & 115 & 13.3 & 23 & 10.8 & 138 & 12.8 \\
\hline Bamboo & 80 & 10.4 & 13 & 6.0 & 103 & 9.5 \\
\hline Barbed wire & 47 & 5.4 & 30 & 13.9 & 77 & 7.1 \\
\hline Concrete wall & 277 & 32.1 & 84 & 38.9 & 361 & 33.4 \\
\hline No fence & 335 & 38.8 & 66 & 30.6 & 401 & 37.1 \\
\hline Total & 864 & 100.0 & 216 & 100.0 & 1080 & 100.0 \\
\hline
\end{tabular}

Source: Field Research, $\left.2014 \quad \mathrm{X}^{2}=27.32, \mathrm{Df}=4, \mathrm{P}<0.05\right)=7.78$

The commonly employed fencing material in Oke-Ogun was concrete wall $(33.4 \%)$ followed by hedges $(12.8 \%)$ and bamboo/wood $(9.5 \%)$ then barbed wire $(7.1 \%)$. In each of the settlement types, concrete wall dominated the sampled buildings that had fence. Rural areas had the greatest proportion of hedges $(20.1 \%)$ while urban areas were of more of barbed wire $(11.7 \%)$ than rural settlements. The chi-square performed across settlement types at $(\mathrm{P}<0.05)$ indicates that the difference in materials used for fence is significant. The implication of this is that there is a significant difference between materials used for fence by households and the settlement types in Oke-Ogun. As expected, the proportion of bamboo/wood among fenced buildings were more in rural than urban areas (see a typical rural fence in Plate 1)

Further analysis revealed that most of the buildings with bamboo/wood were used for residential/agricultural purpose. Further investigation also revealed that most of the building that made use of hedge as fence material was of old types. The use of hedges as security barrier is not adequate in this modern age when criminal are more daring and sophisticated in their nefarious activities.

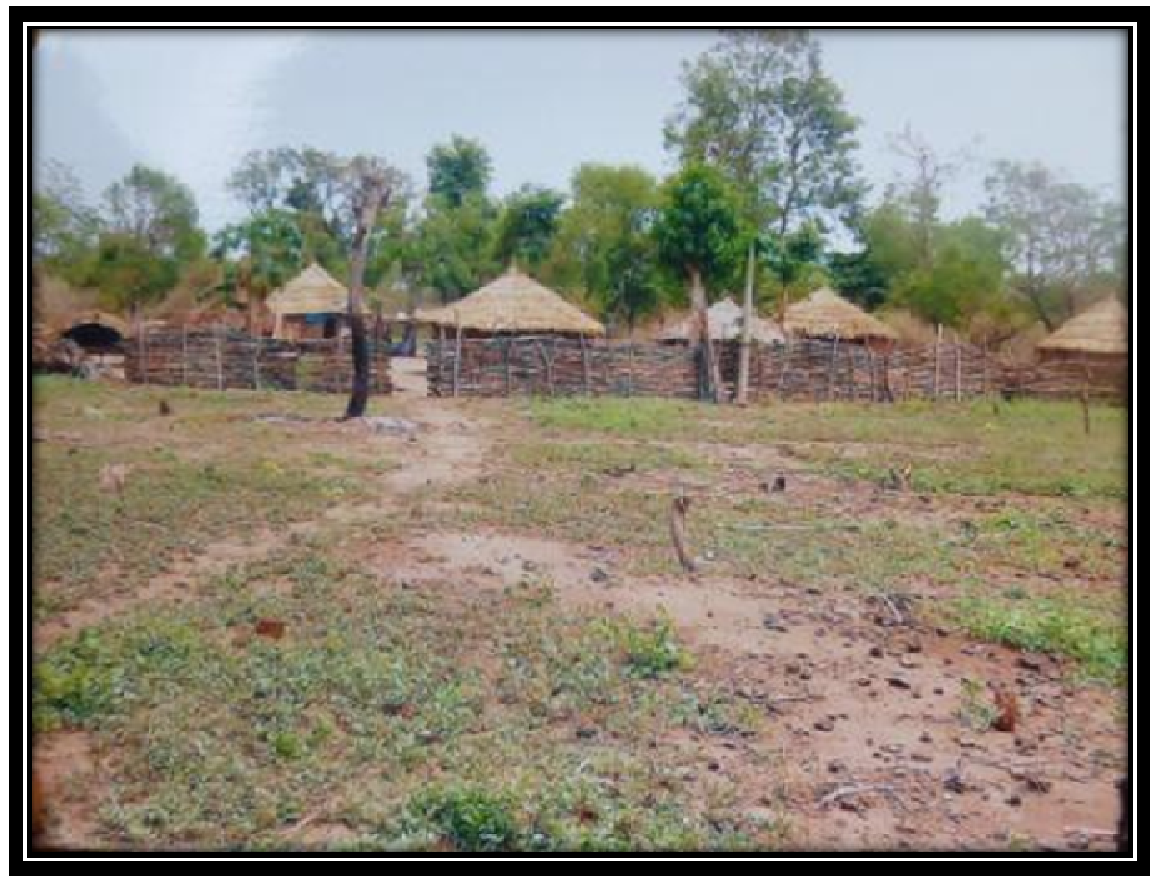

Height and Material on Fence

Plate 1: Fenced Materials in the rural areas

The level of security consciousness of households was not only revealed by the material used for fencing, it was also shown by the height of fence and the materials on the top of the fence. In city planning and building industry, the commonly recommended height of ideal concrete fence for residential building is between 1.00 and 3.00 metres (see Plate 2). The concrete if imperforated should not be more than 1.00 metres. Therefore, an ideal building fence should be made up of perforated blocks or iron/steel works with inserted spaces which should be on top of 1.00 metres imperforated fencing materials. 


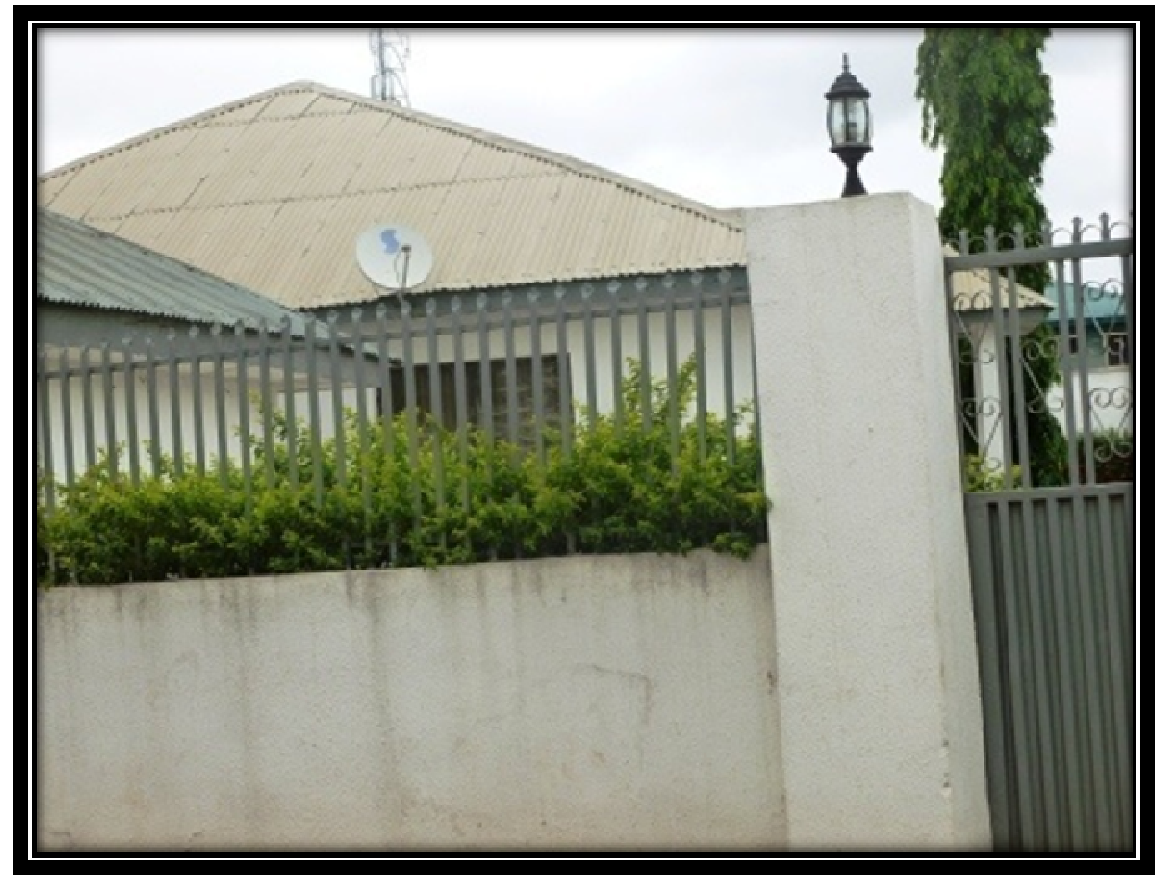

Plate 2: An Ideal Fence

The specification is fully adopted in Abuja city planning and it is highly enforced on developers. This specification, while supporting maximum security does not undermine the healthy living and the aesthetic value of buildings. Fences that are imperforated tend to undermine ventilation and sink the visual beauty of buildings into oblivion. This often sends signal that there are likely valuable materials which needed to be protected in such buildings. Among sampled buildings that had fences, $27.8 \%$ of them had estimate height that ranges between 2.0 and 2.5 metres and $11.6 \%$ with heights above 3.0metres (Table 6). The highest concentration of sky rocketing fences in the urban settlements might be due to the fact that multi-storey buildings were more concentrated in these settlements.

Table 6: Height of Fences

\begin{tabular}{|c|c|c|c|c|c|c|}
\hline \multirow{3}{*}{ Height range } & \multicolumn{4}{|c|}{ Settlement } & & \\
\hline & \multicolumn{2}{|l|}{ Rural } & \multicolumn{2}{|c|}{ Urban } & \multicolumn{2}{|c|}{ Total } \\
\hline & Freq & $\%$ & Freq & $\%$ & Freq & $\%$ \\
\hline $1.0-1.5 .0 \mathrm{~m}$ & 101 & 19.5 & 50 & 30.5 & 151 & 22.2 \\
\hline $1.5-2.0 \mathrm{~m}$ & 153 & 29.6 & 17 & 10.4 & 170 & 25.0 \\
\hline $2.0-2.5 m$ & 147 & 28.4 & 42 & 25.6 & 189 & 27.8 \\
\hline $2.5-3.0 \mathrm{~m}$ & 62 & 12.0 & 30 & 16.3 & 92 & 13.5 \\
\hline Above $3.0 \mathrm{~m}$ & 54 & 10.4 & 25 & 15.2 & 79 & 11.6 \\
\hline Total & 517 & 100.0 & 164 & 100.0 & 681 & 100.0 \\
\hline
\end{tabular}

Source: Field Research, $2014 \quad \mathrm{X}^{2}=31.96, \mathrm{Df}=4(\mathrm{P}<0.05)=7.78$

Substantial proportion of the buildings with no material on top of the fence in the rural settlements was $29.6 \%$ compared with urban settlement with $23.0 \%$ (Table 7 ). In line with expectation, $15.7 \%$ of buildings with materials on fence had broken bottles on top in the urban settlement, and $12.8 \%$ in the rural settlements. From every indication, it is crystal clear that urban settlements were more security conscious than rural settlement because they were made up of heterogeneous people with divorced behaviours and motives. The use of burglar guard, fence, and material on fence, transparent doors and window as physical barrier helps in monitoring and or restricting unduly physical access. They are also efficient element of demarcating, various zones of defence. Entrances into certain parts of buildings are restricted with effective use of the aforementioned materials and the like. In Oke-Ogun, the buildings that were recently constructed were made of high fences that dwarfed bungalows and on these fences were mounted materials to serve as deterrent to undesirable elements that might want to scale the walls (see Plate $3 \& 4$ ), Materials on fence-bricks varied from broken bottles (13.5\%), to spiral barbed wire $(12.4 \%)$ or net barbed wire $(37.0 \%)$ with the barbed wire being sometimes electrified to iron nails $(9.0 \%)$ 
Table 7 Materials on Top of Concrete Fence

\begin{tabular}{|l|l|l|l|l|l|l|}
\hline \multirow{3}{*}{ Material } & \multicolumn{7}{|l|}{ Settlement } \\
\cline { 2 - 7 } & \multicolumn{2}{|l|}{ Rural } & \multicolumn{1}{l|}{ Urban } & Total \\
\cline { 2 - 7 } & Freq & $\%$ & Freq & $\%$ & Freq & $\%$ \\
\hline None & 171 & 29.6 & 41 & 23.0 & 212 & 28.0 \\
\hline Broken bottle & 74 & 12.8 & 28 & 15.7 & 102 & 13.5 \\
\hline Spiral barbed wire & 73 & 12.6 & 21 & 11.8 & 94 & 12.4 \\
\hline Iron-nails & 61 & 10.6 & 7 & 3.9 & 68 & 9.0 \\
\hline Net barbed wire & 199 & 34.4 & 81 & 45.5 & 280 & 37.0 \\
\hline Total & 578 & 100.0 & 178 & 100.0 & 756 & 100.0 \\
\hline
\end{tabular}

Source: Field Research, $2014 \quad \mathrm{X}^{2}=14.16 \mathrm{Df}=4(\mathrm{P}<0.05)=7.78$

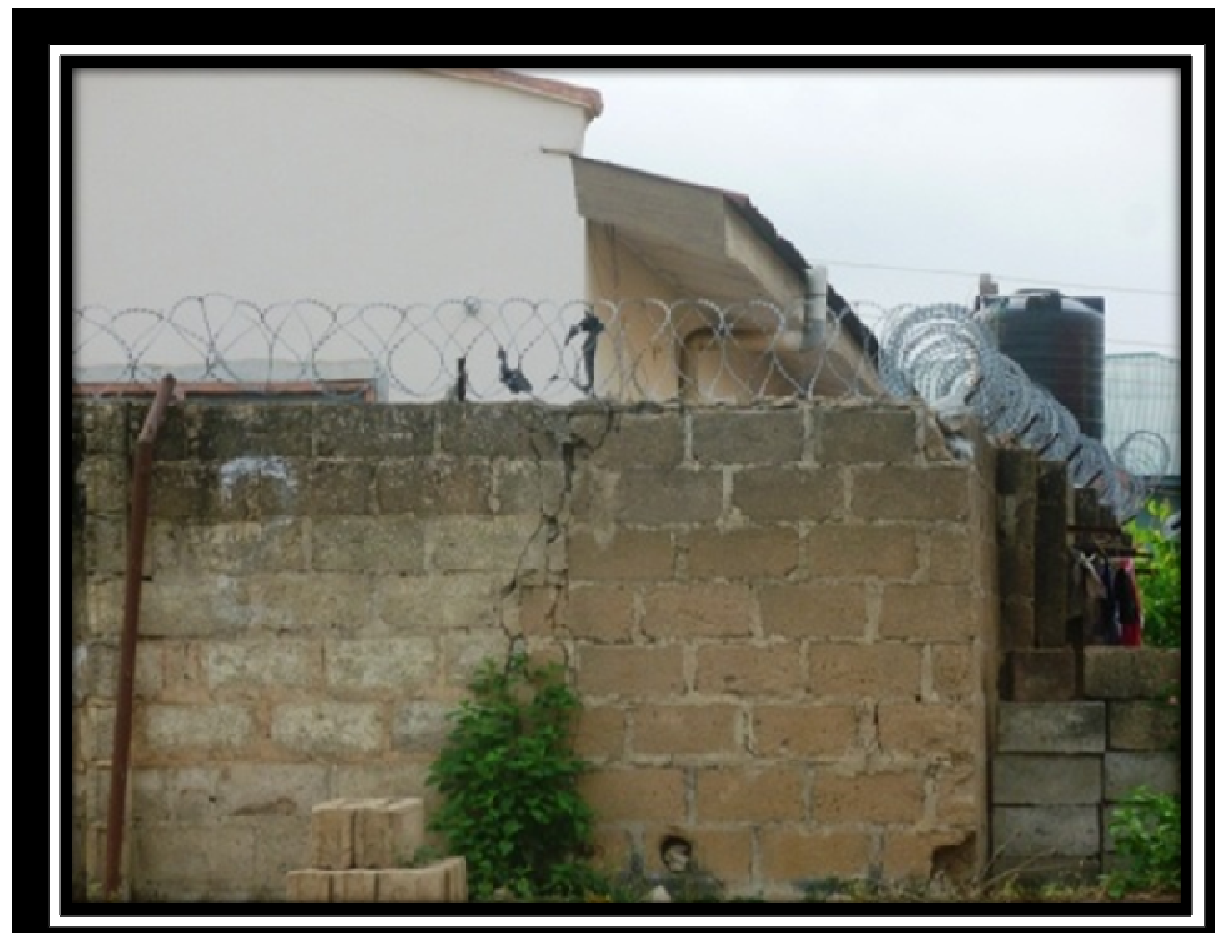

Plate 3: A Typical Fenced Building in the Urban Areas 


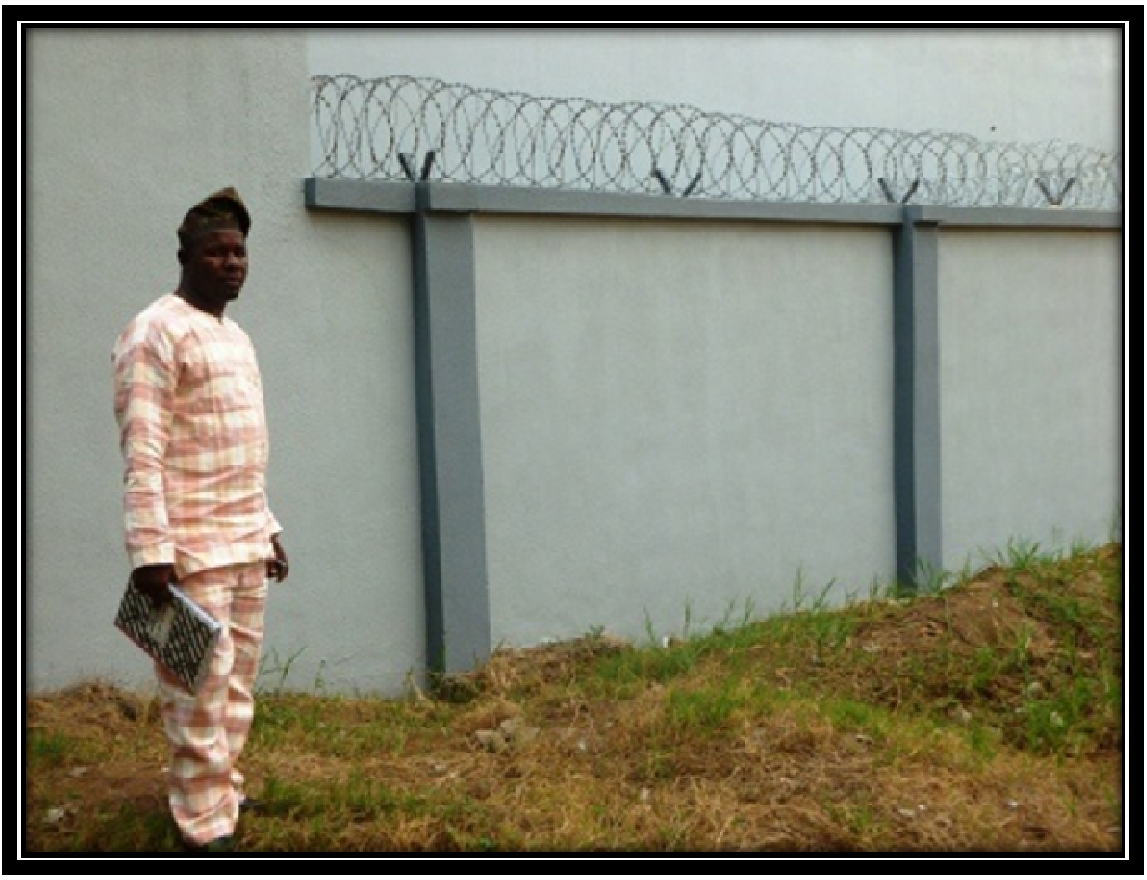

Plate 4: A Typical Fence that Dwarfs Building in Urban Areas

Street Features Present within Settlement Types

In the study area, the percentage share of each feature present goes thus; bumps (13.9\%), street gate $(52.5 \%)$, security check point $(8.8 \%)$, warning sign or restriction $(12.2 \%)$. A substantial proportion of buildings with street gates $(79.9 \%)$ were found in the urban settlements (Table7.8).

Table 8 Streets Features within Settlement Types

\begin{tabular}{|l|l|l|l|l|l|l|}
\hline \multirow{2}{*}{ Location of Burglary } & \multicolumn{6}{|c|}{ Settlement } \\
\cline { 2 - 7 } & Rural & Urban & Total \\
\hline & Freq & $\%$ & Freq & $\%$ & Freq & $\%$ \\
\hline Bump & 90 & 14.0 & 28 & 13.4 & 118 & 13.9 \\
\hline Gate & 280 & 43.6 & 167 & 79.9 & 447 & 52.5 \\
\hline Check point & 67 & 10.4 & 8 & 3.8 & 75 & 8.8 \\
\hline Warning sign & 100 & 15.6 & 4 & 1.9 & 104 & 12.2 \\
\hline Others & 105 & 16.4 & 2 & 1.0 & 107 & 12.6 \\
\hline Total & 642 & 100.0 & 209 & 100.0 & 851 & 100.0 \\
\hline
\end{tabular}

Warning signs or restriction as observed on streets include nobody is allowed to pass through this area between 11 o'clock p.m. and 5 o'clock a.m. Beware of dogs, you are under surveillance beware etc.). Bumps made on the streets were not only means of controlling reckless driving in the neighbourhood but ways of trapping the thieves on bike. Bumps in some neighbourhood especially in the urban settlements were used as check point by security men to authenticate the right ownership to vehicles because cyclists and drivers had to slow down to the barest minimum speed before passing through the bumps. The general thought of people that bumps retard the speed of escaping criminals was debunked by others that bumps were favourite spots for vehicle snatchers at night to punch on unsuspecting vehicle owners slowing down at bumps.

\section{(ii) Surveillance Structure in Oke-Ogun}

\section{Use of Security Measures in the Study Area}

The use of private security personnel was at its lowest ebb in Oke-Ogun area and only 8.9\% of households sampled signifying the usage. Out of this, a small proportion of households, $9.4 \%$ in the urban and $8.8 \%$ in rural settlements were with private security guards manning individual buildings in the study area (Table 9). The low usage of private security personnel/guards across the settlement types in Oke-Ogun might be due to the occupational status and the low level of income of the inhabitants.

It was observed that the use of private security guards was an option available to a wealthy minority. The use of vigilante group as surveillance measure by households, whether undertaken by residents or persons paid by the community was widespread in Oke-Ogun in every settlement type, and it considerably varied across settlement types. At aggregated level, $26.6 \%$ of all households sampled in rural and urban settlements made use 
of vigilante group. From the aggregate percentage of $24.4 \%$ of sampled households in Oke-Ogun that made use of security dogs, rural households $(26.2 \%)$ dominates followed by urban households (24.4\%). Appliances at home were very rare to come by in rural areas, while $17.6 \%$ of sampled urban households made use of appliances at home, $0.3 \%$ of the sampled rural households made use of it. The total aggregate percentage of all buildings sampled for the use of appliances at home was $4.3 \%$. The total number of respondents surveyed that declared the use of charm as protective measure was $5.5 \%$ and the use were in ascending order from rural to urban areas. Households in the urban areas were more security conscious than rural settlement in Oke-Ogun

Table 9 Uses of one or more Security Measures across Settlement

\begin{tabular}{|l|l|l|l|l|l|l|}
\hline \multirow{2}{*}{ Security Measures } & \multicolumn{7}{|c|}{ Settlement } \\
\cline { 2 - 7 } & Rural & Urban & Total \\
\cline { 2 - 7 } & Freq & $\%$ & Freq & $\%$ & Freq & $\%$ \\
\hline Private security firm & 99 & 8.8 & 32 & 9.4 & 131 & 8.9 \\
\hline Vigilante group & 334 & 29.5 & 58 & 17 & 392 & 26.6 \\
\hline Local night watch men & 156 & 13.8 & 33 & 9.7 & 189 & 12.8 \\
\hline Security dog & 296 & 26.2 & 63 & 18.4 & 359 & 24.4 \\
\hline Appliances at home & 03 & 0.3 & 60 & 17.6 & 63 & 4.3 \\
\hline Burglar proofing & 102 & 9.0 & 51 & 14.9 & 103 & 10.4 \\
\hline Fencing & 81 & 7.1 & 22 & 6.5 & 103 & 6.9 \\
\hline Charm & 60 & 5.3 & 22 & 6.5 & 82 & 5.6 \\
\hline Total & 1131 & 100.0 & 341 & 100.0 & 1472 & 100.0 \\
\hline
\end{tabular}

Source: Field Research, 2014

Functional Street Light

An affirmation of good functioning of street light was very low in the study area. Only $18.1 \%$ of all respondents in Oke-Ogun gave opinion that the functionality of street light was good while $25 \%$ of the respondents said that the functionality was fair. Of all respondents, $43.4 \%$ gave opinion that the functionality of street light was bad, and $13.5 \%$ of the respondents gave no opinion because there was no street light in their residences (Table 10).

Table 10: Functionality of Street Light

\begin{tabular}{|l|l|l|l|l|l|l|}
\hline \multirow{3}{*}{ Functionality } & \multicolumn{6}{|c|}{ Settlement types } \\
\cline { 2 - 7 } & Rural & Urban & Total \\
\cline { 2 - 7 } & Freq & $\%$ & Freq & $\%$ & Freq & $\%$ \\
\hline Good & 138 & 15.7 & 59 & 27.8 & 195 & 18.1 \\
\hline Fair & 177 & 20.5 & 93 & 43.5 & 270 & 25.0 \\
\hline Bad & 423 & 48.9 & 45 & 21.0 & 468 & 43.4 \\
\hline No opinion & 129 & 14.9 & 17 & 7.8 & 146 & 13.5 \\
\hline Total & 865 & 100.0 & 214 & 100 & 1079 & 100.0 \\
\hline
\end{tabular}

Source: Field Research, $2014 \quad \mathrm{X}^{2}=86.47 \mathrm{Df}=3(\mathrm{P}<0.05)=6.25$

Further analysis therefore revealed that the significant proportion of respondents across settlement types who gave opinion that the functionality of street light was good and fair majorly based their opinion on newly erected solar light in some wards in the study area. More so, analysis revealed that not more than $5 \%$ of all streets in towns of Oke-Ogun had street light. This implies that greater portion if not total, of the town would be in the darkness at night time, thus creating avenue for devilish works of night marauder. The situation might be worse in the rural settlements. And this might be the major reason why most houses made use of security dogs in rural and urban settlements for giving alerts on street marauder in the night.

Policy/ Planning Implication and Conclusion

The observed high fences that dwarf the buildings in the study area manifested unhealthy consciousness of crime that might threaten the community's psyche with terror, and the failure of regulatory bodies. This violates the right height for the right construction for the right purpose in order to achieve spatial functionality that will not undermine ventilation. For planning and policy oriented remark, it is therefore suggested at this point in time that more Police officers should be recruited to monitor vulnerable spaces to augment the use of vigilante group that was widely spread and officers be strengthened with sophisticated security gadgets. These, apparently, would help partly to reduce the volume of crime occurrences in general and partly to redistribute criminal activities spatially. The argument being that as far as no area has more than its share of criminality, all things being be equal, no problem area would become incurable and pervasive in its effect if attacked at the present time. It is recommended that height of ideal concrete fence for residential building should not be more than within 1.5 metres. The concrete if imperforated should not be more than 0.9 metre. Therefore, an ideal building fence should be made up of perforated blocks or iron/steel works with inserted spaces which should be on top of 0.6 
metre imperforated fencing materials. The specification if fully adopted and highly enforced on developers will not only support maximum security but will not undermine the healthy living and the aesthetic value of buildings. Fences that are imperforated tend to undermine ventilation and sink the visual beauty of buildings into oblivion. This often sends signal that there are likely valuable materials which needed to be protected in such buildings.

The study concluded that protective measure adopted in Oke-Ogun to check crime prevalence varied spatially and that could be broadly classified into personal and collective efforts. Personal efforts were individual efforts and include fixing door and window guards, erection of fence, fixing of lighting systems, employment of private security men, use of alarm system, use of weapons (gun, cutlass, axe, and club) security dogs and traditional protective devices. The collective efforts were households' efforts or public efforts aimed at controlling crime. The collective efforts as identified in the study area included landlord/tenants vigilante group, hiring of local security guard of Oodua people congress members at community level to safeguard residences. It was observed that the use of private security guards was an option available to a wealthy minority. There were also household/Police joint efforts which manifest through the activities of Police public Relation committee but the activities were not given much recognition in most of the communities.

\section{REFERENCES}

Adeagbo, D. (2001) "Security of Lives and Property in the Peri-Urban: An Assessment of the Efforts of Landlords/Tenants Associations." Paper presented at the International Conference on Security, Segregation and Social Networks in West Africa Cities $19^{\text {th }}-20^{\text {th }}$ centuries, held at the International Centre for African Studies (IFRA) University of Ibadan, $29^{\text {th }}-31^{\text {st }}$ October, 2001

Adeboyejo, A.T and Abodunrin F.O. (2007) Spatio-Temporal Variation in Urban Crime in Ogbomoso. Global Journal of Environmental Sciences. Vol 6, No1 pp 21-26

Adejumobi, C.A. Oni, N.O. and Ige, J.O. (2009) "Crime Occurrence and Community Policing in Southwestern Nigeria". Journal of Social Policy and Society. Vol 4, No 1, pp 112-119

Adigun, F.O. (2012) Spatio-Temporal Analysis of Urban Crime in selected Nigerian Cities. PhD Thesis, Department of Urban and Regional Planning, Ladoke Akintola University of Technology.

Agbola, T. (1997) Architecture of fear, Urban Design and Construction. Response to Urban Violence in Lagos, Nigeria. Ibadan. IFRA

Agnew, R. (1999) “A General Strain Theory of Community Differences in Crime Rates.” Journal of Research in Crime and Delinquency, Vol. 36, pp.123-155

Aguda, A.S (1994) "Areal and Ecological Analysis of Crime: A Case Study of a Nigerian City". In Albert, I.O, Adisa, J. Agbola, T. and Herualt, G (Eds) Urban Management and Urban Violence in Africa. Vol 1 pp 1-8. Ibadan: IFRA

Albert, I.O. (1994) "Urban violence in Contemporary Africa: Some Theoretical Exploration”. In Albert, I.O, Adisa J., Agbola T. and Herault, G. (Eds) Urban Management and Urban Violence in Africa. Vol 1 pp 920. Ibadan IFRA

Akinrinde, S. (2007) "Menace of Bandits", Newswatch Magazine, April 22, Lagos: Newswatch Communication Limited.

Alemika, E.E.O. (2006) "Crime Statistics and Information Management in Nigerian Justice and Security Systems". In Alemika, E.E.O. and Chukwuma, I. (Eds). Crime and Policing in Nigeria: Lagos, Nigeria, Centre for Law Enforcement Education.

Alemika, E.E.O. and Chukwuma, I. (2000) Police-Community Violence in Nigeria. Lagos, Nigeria: Centre for Law Enforcement Education.

Allen, M. (2009). Remote and northern policing. RCMP Gazette, Retrieved August 25, 2011, from http://www.rcmp-grc.gc.ca/gazette/vol71n1/c-ontario-eng.htm

Anderson, S. (1999). "Crime and Social Change in Scotland". In G. Dingwall and S. Moody. (Eds.). Crime and Conflict in the Countryside. Cardiff: University of Wales Press.

Arinze, P. E (2010) "An Evaluation of the Effects of Armed Robbery on Nigeria Economy", Trans-campus Journal of Research in National Development, Vol. 8, No.2, pp12

Aust, R. And Simmons, J. (2002) Rural crime: England and Wales. Home Office Statistical Bulletin 01/02. London: Home Office

Ayeni-Akeke, A. (2001) "Collective Violence and Insecurity in Nigeria cities: Some Theoretical Consideration". Paper Presented at the International Conference on Security Segregation and Social Network in West Africa Cities $19^{\text {th }}-20^{\text {th }}$ centuries held at the International Centre for African Studies (IFRA) University of Ibadan Oct $29^{\text {th }}-31^{\text {st }}, 2001$.

Bellair, P.E. (1997) "Social Interaction and Community Crime: Examining the Importance of Neighbourhood Networks”, Criminology, Vol. 35, pp. 677-703 
Bottoms, A.E. and Willes, P. (1995) "Crime and Insecurity in the City", In C. Fijnat et.al (Ed) Changes in Security, Crime and Criminal Justice in Europe, two vols. The Hague: Kluwer

Brantingham, P.L and Brantingham, P.J. (1995) "Environmental Criminology and Crime Prevention", In P.O.H. Wilkstrom, R.V. Clark and J. McCord (Eds), Integrating Crime Prevention Strategies: Propensity and Opportunity, National

Bursik, R.J. 1984, "Ecological Stability and the Dynamics of Delinquency", In A.J.

Reiss and M. Tonry,(eds), Communities and Crime, University of Chicago Press,

Chicago, pp 35-66.

Ehrlich, I. (1996) "Crime, Punishment and the Market of Offences". Journal of Economic Perspectives, Vol. 10, pp 43-68.

Elliot, D.S., Wilson, W.J., Huizinga, D., Sampson, R.J.,Elliot, A.and Rankin, B.(1996) "The Effects of Neighbourhood Disadvantage on Adolescent Development", Journal of Research in Crime and Delinquency, Vol. 33, pp 389-426.

Faris, R.E.L and H.W. Dunham (1993) Mental Disorder in Urban Areas. Chicago: University of Chicago Press.

Felson, M. (1998) " $\left\{\right.$ Crime and Everyday Life": $2^{\text {nd }}$ Ed, Pine Forge Press, Thousand Oaks.

French Institute for Research in African IFRA (1997): Youth, Street, Culture and Urban Violence in Africa, Report of International Symposium held in Abidjan, May $5^{\text {th }}-7^{\text {th }}$ IFRA/African Book Builder, Ibadan: pl.

Fisher, B., and Looye, J. W. (2000) "Crime and Small Business in the Mid-West: An Examination of Overlooked Issues in the United States”. Security Journal, Vol. 13, No. 2, pp45-72

Fisher, J.L (1955) "Concept in Regional Economic Development" Papers and Proceedings of the Region of Science Association, Vol 5. pp 57-58.

Friendmann, J. (1966) Regional Development Policy: A Case Study of Venezuela, Cambridge, Massachusetts: The John Hopkins Press.

Friedman, W. (1995). Research, organizing and the campaign for community policing in Chicago. In Nyden et al. (Eds.), The Collaborative Community: New models for social research. Thousand Oaks, CA: Pine Forge Press.

Fung, A. (2001) “Accountable Autonomy: Toward Empowered Deliberation in Chicago Schools and Policing”. Politics and Society. Vol. 29 No1, pp 73-103.

Gana, R.N. (1995) “A Comparative Analysis of Development Control Implementation in Minna and Bida, Niger State". Ph.D Thesis submitted to the Department of Geography, University of Ilorin, Nigeria.

Gardner, R. (1995) Crime prevention Through Environmental Design (CPTED) Security Management Magazine, April edition.

Garriott, W. (2010) "Targeting the local: Policing Clandestine Methamphetamine Production in a rural US Community". Canadian Journal of Law and Society, Vol 25 No1, pp 1-19.

Ige, J.O. (2000) Urban Residents' Perception of and Response to Crime. A Case of Oyo Town, Nigeria. Unpublished B.Tech Dissertation, Department of Urban and Regional Planning, Faculty of Environmental Sciences, Ladoke Akintola University of Technology, Ogbomoso.

Ige, J.O. (2008) Geo-digital Mapping and Spatial Analysis of Crime in Saki West Local Government Area of Oyo State, Nigeria. Unpublished M.sc Thesis, Department of Geography, Faculty of Social Sciences, Obafemi Awolowo University, Ile-Ife

Ige. J.O., Aloba, O. and Aboyeji, S.O. (2010) “Agro-crime and Rural Agriculture Sustainability: An Experience in Guinea Savannah of Nigeria". Journal of Research in Agriculture, Vol 8 No1, pp 6-8.

Lawtley, A. and Deane, M. (2000). Community safety in rural areas. NACRO. From http://www.nacro.org.uk/data/briefings/Nacro-2000071002-csps.doc

Longley, P.A. (2001) Geographic Information System and Science. London: Prentice Hall International Inc.

Madden J. (1996) "Violence and its Effects on Women's Access to Social services". The Urban Age. Vol 4, No 2 pp. 16

Mawby, R.I. (2006) "Crime, Place and Explaining Rural Hotspots". Paper presented at the Crime in Rural Communities Conference, Rural Crime Centre, University of New England, Armidable, New South Wales, online

Mawby, R. I. (2004). "Myth and reality in rural policing: Perceptions of the Police in a rural county of England. Policing": An International Journal of Police Strategies and Management, Vol. 27 No 3: pp 431-446

Merry, S.E. (1981) "Defensible Space Undefended: Social Factor in Crime Control through Environmental Design." Urban Affairs Quarterly Vol 16, pp 397-422.

Mingay, G. (Ed.) (1989) The Rural Idyll. London: Routledge

Newman, O. (1995) “Defensible Space: Crime Prevention through Urban Design”. In Stein, Jay M, (Eds), Classic Readings in Urban Planning USA: Mc Graw-Hill, Inc. pp 208- 226.

Neuman, W.L (1994) Social Research method: Qualitative and Quantitative Approaches, Allyn and Vacon, 
Massachussets.

Neuman, W.L (1991) Social Research method: Quantitative and Qualitative Approaches, Second Edition Boston, London: Toronto, Sydney, Tokyo and Singapore: Allya and Bacon

Obateru, O.I (2003) Land Subdivision Basic. Penthouse Publication, Ibadan, Nigeria

Obateru, O.I (1994) "Planning the City to Mitigate Urban Violence". In Albert, O.I, Adisa J., Agbola,T. and Herault, G. (Eds) Urban Management and Urban Violence in Africa.Vol. 1. Ibadan: IFRA

Obudho, R.A. and Owuor, S.O. (1994) Urbanization and Crime in Kenya. In Albert, I.O.,Adisa, J., Agboola, T. and Hearault, G. (Eds) Urban Management and Urban Violence in Africa. Vol.1 pp 41-42 Ibadan: IFRA.

Odekunle, F. (1982) "Crime and Social Defence", in Akeredolu, A. (Ed.) Social Development in Nigeria: A Survey of Policy Research. Oxford University Press, Ibadan. Pp 67 - 92

Odekunle, F. (2005) "Crime and Social Deviance", in Akeredolu, A. (Ed.) Social Development in Nigeria; Ibadan: University Press Ltd, Pp 68

Okafor S.I (2004) "Regional Development Planning": in Agboola, T. (Ed.) Readings in Urban and Regional Planning. Macmillan Nigeria Publishers Limited, Yaba, Lagos.

Okoko, E (2000) Quantitative Technique in Urban Analysis, Ibadan: Krafts Book Limited.

Okoko E (2008) "A Time-Series Analysis of the Trend of Urban Violence in Akure, Nigeria". Journal of Nigerian Institute of Town Planners. Vol. 21, No1 pp 166-183

Okunola, R. A. (2002) "Crime in Society: Current and Perspective" in Uche Abanihe, Austin Isamah and Jimi Adesina (Eds) Current and Perspective in Sociology, Lagos: Malthouse Press Ltd, pp349-366

Olatunji, S. and Abioye, O. (2011) Lecturers, Students, Others Killed in Kaduna. The Punch, Wednesday, April 20.

Omisakin, I.S. (1998) "Crime Trends and Prevention Strategy in Nigeria”. A study of Old Oyo State": NISER Monograph pp1-7.

Omuta G.E.D and Onokerhoraye,A.C. (1986) Regional Development and Planning, University of Benin Press.

Onyenechere, E.C. (2011) "The informal Sector and the Environment in Nigerian Towns: What We Know and What We Still Need to Know". Research Journal of Environmental and Earth Sciences- Vol 3 No1, pp6169

Onyeozili, E. C. (2008) "Obstacles to Effective Law Enforcement in Nigeria”, African Journal of Criminology and Justice Studies, Vol. 1, No. pp11-23

Oredein, S. A, (2006). An Assessment of Households Response to Crime in Abuja. M.Tech Dissertation, Department of Urban and Regional Planning, Ladoke Akintola University of Technology, Ogbomoso

Openshaw, S., Waugh, D. and Charlton, M. (1994) "Some Ideas about the Use of Map Animation as a Spatial Analysis Tool", in R.A. Earn Shaw and D. Watson (Eds) Animation and scientific Visualization: Tools and Application. London: Academic Press.

Padgett, D. A. (2000) Downtown has greater potential than people realize. The Tennessean.

Paresi C. (2000) Handouts Information System Development and Spatial Database Design: ITC Netherlands.

Peets, R. (1975) “The Geography of Crime: A Political Critique”. The Professional Geographer. Vol. 27 , No 3. pp 227

Phillips, J. and Goodstein, E. (2000) "Growth Management and Housing Prices: The case of Portland Oregon". Contemporary Economic Policy; Vol. 18, No. 3, pp334-344.

Rankin, D. (1996)"The Effects of Neighbourhood Disadvantage on Adolescent Development” Journal of Research in Crime and Delinquency, Vol. 33, p. 389 - 406.

Reno J. (1999) "Crime and ESRI”, in Nelson, L. (Ed.) Crime Mapping News: Police Foundation, Washington DC.Vol.1 p.12

Richardson, H.W. (1974), Region growth theory; The Macmillan Press Limited.

Rolnik, R. (1999) Territorial Exclusion and Violence: The case of Sao Paulo, Brazil. Occasional Paper Series on Comparative Urban Studies, (Washington D.C: Woodrow Wilson International Centre for Scholars).

Rosenbaum, D.P. (1987). "The theory and research behind neighborhood watch: Is it a sound fear and crime reduction strategy?” Crime and Delinquency, Vol. 33No 1, pp 90 - 102.

Rosenbaum, D.P. Lurigio, J. (1994) “An Inside Look at Community Policing Reform: Definitions, Organizational Changes, and Evaluation Findings. Crime and Delinquency, Vol. 40 No 3, pp 299-314.

Rotimi, K. (2001) “The Police in a Federal State: The Nigerian Experience, Ibadan, Nigeria." College Press

Rountree, P. W. and Land, K. C. (2000) "The Generalizability of Multilevel Models of Burglary Victimization," A Cross-City Comparison. Social Science Research, Vol. 29, pp284-305.

Saddler, D. (1999) "Why Map" Crime Mapping Research Centre, National Institute of Justice, U.S. Department of Justice. New York. pp 9-13.

Sampson, R.J. (1995) “The Community”, In J.Q. Wilson and J. Petersilla (Eds), Crime, ICS Press, San Francisco,

Sampson, R. J. (2002) Organized for What? Recasting Theories of the Social (Dis) Organization. In Waring, E. 
and Weisburd, D., (Eds), Crime and Social Organization. Transaction Publishers, New Brunswick, NJ.

Sampson, R.J. and W.B. Groves (1989) "Community Structure and Crime: Testing Social-Disorganization Theory”, American Journal Sociology, Vol. 227, pp 918-924.

Sampson, R.J., Raudenbusch, S.W and F. Earls (1997) "Neighbourhoods and Violent Crime: A Multilevel Study of Collective Efficacy", Science Vol. 227, pp 918-924.

Sampson, R. J. (1995): "The community": In Wilson, James, Q., Petersilia, and Joan (Eds), Crime. San Francisco California: ICS Press, pp 193-216.

Schneider, A.L. (1987). "Coproduction of public and private safety: An analysis of bystander intervention, protective neighboring, and personal protection". Western Political Quarterly, Vol. 40 No 4, pp 611-630.

Shaftoe, H. (2002) "Social Crime Preventions to Reduce the Motivation to Offend". Synopsis of Presentation at Tallinn City Council $15^{\text {th }}$ April.

Shevky, E. and Ball, W. (1955): Social Area Analysis: Theory, Illustration, Application and Computation Procedure,.StanDford, California: StanDford University Press.

Shaw, C.D and McKay, H. (1949) "Rejoinder", American Sociological Review, Vol. 14, pp 614-617.

Sherman,L.W., Gartin, P.R. and M.E Buerger (1989) "Hot spots of Predatory Crime: Routine Activities and the Criminology of Space", Criminology, Vol. 17 pp 17-49.

Singer, P (1997) Social Exclusion in Brazil (Geneve: International Institute for Labour Studies Labour Institutions and Development Programme)

Singleton, R. (1988): Approaches to Social Research. New York, Oxford University Press, pp 145-147.

Skogan, W., and Hartnett, S. (1997). Community policing: Chicago style. New York: Oxford University Press.

Smith, D.M. (1993) The Geography of Social Wellbeing in the United States. New York, McGraw-Hill.

Smith, W. R., Frazee, S. G., and Davison, E. (2000) "Furthering the Integration of Routine Activity and Social Disorganization Theories: Small Units of Analysis and the Study of Street Robbery as Diffusion". Criminology, Vol. 38, No. 2, pp489-523.

Sparrow, M.K., Moore, M.H., and Kennedy, D.M. (1990). Beyond 911: A new era for policing. New York: Basic Books

Tabachnick, B.G.and Fidell, S.L (2001) Using Multivariate Statistic, Fourth Edition, Ally and Baccon, USA pl.

Tanumo, T.N (1991) Peace and Violence in Nigeria 'The Panel on Nigeria since Independence History Project. University of Ibadan, Ibadan.

The Punch, (2011), "Boko Haram Bombs Police Headquarters at Louise Edet House, Abuja" The Punch National Newspaper Friday $17^{\text {th }}$ June, 2011

Vanderschueren, D. (1996) "From violence to Justice and Security in cities". Environmental and Urbanization. Vol 8 No1 pp 93-112

Versey, B. and Messner, S.F. (1999) "Further Testing of Social Disorganisation Theory: An Elaboration of Sampson and Groves". Community Structure and Crime. Journal of Research in Crime and Delinquency, Vol. 36, pp $156-174$.

Walklate, S. (1996) Community and Crime Prevention. In McLaughlin, E. And Mumic, J. (Eds) Controlling Crime. London: Sage Publication.

Weatherburn, D..and Lind, B. (1997) Social and Economic Stress, Child Neglect and Juvenile Delinquency, NSW Bureau of Crime Statistics and Research, Sydney. pp 1825

Weisburd, D. and McEwen, T. (1997) “Crime Mapping and Crime Prevention”, In D. Weisburd and T. McEwen (Eds). Crime Mapping and Crime Prevention, Crime Prevention Studies, Vol. 8 pp 1-26.

Weisheit, R.A., Falcone, D.N., and. Wells, L.E.(2006). Crime and Policing in Rural and Small- Town America. $3^{\text {rd }}$ edn. Prospect Heights, Illinois: Waveland Press.

Wendt, S. (2009) Domestic violence in rural Australia. Sydney: The Federation Press.

Wikstrom, M. (1998) "Social Capital and Economic Development: Toward a Theoretical Synthesis and Policy Framework", Theory and Society Vol. 27, No 2, pp 151 - 208

Williams, B. (1999) "Rural Victims of Crime". In G. Dingwall and S.Moody. (Eds). Crime and Conflict in the Countryside. Cardiff: University of Wales Press.

Wilson, J.Q. and Kelling, G.L. (1989) "Making neighborhoods safe: Sometimes 'fixing brok windows' does more to reduce crime than conventional 'incident-oriented' policing". Atlantic Monthly, Vol 263 No 2, pp $46-52$.

Wofgang, M.E. and Ferracuti, F. (1967) Subculture of Violence, Towards an Integrated Theory in Criminology, Tavistock, New York.

Yarwood, R. . (2007). "Getting just Deserts? Policing, Governance and Rurality in Western Australia. Geoforum, Vol 38 No 2, pp 339-352

Yongcho, Hyo (1974) Public Policy and Urban Crime. USA, Ballinger Publishing Company 